\title{
A Study on Cross-Cultural Management of FAW-Volkswagen
}

\author{
GAO Yufeng \\ Wuhan University of Technology, Wuhan, 430070 China
}

\begin{abstract}
With the deepening of Economic Reform and Open up, more and more foreign-funded enterprises come to China to invest and set up Sino-foreign joint ventures. Due to the differences in cultural backgrounds between the two sides of Sino-foreign joint venture, cultural conflicts are inevitable. Proper cross-cultural management mechanism is the most effective measure to eliminate cultural conflicts in Sino-foreign joint ventures, while the complex business environment and the diverse personnel structure are the problems that cross-cultural management faces. FAW-Volkswagen Automotive Co., Ltd. (hereinafter referred to as FAW-Volkswagen), as one of the most successful large-scale Sino-foreign joint ventures in China, has accumulated a lot of fruitful experience in the field of cross-cultural management. Its cross-cultural management experience is a good reference for other Sino-foreign joint ventures. Based on Corporate Culture Theory, Cross-Cultural Management Theory, and the cross-cultural management experience of FAW-Volkswagen, this paper will propose a general cross-cultural management model applicable to other Sino-foreign joint ventures.
\end{abstract}

Keywords: Sino-foreign joint venture, FAW-Volkswagen, corporate culture, cross-cultural management

\section{Introduction}

With the development of Global Economic Integration and the deepening of Economic Reform and Open up, more and more foreign-funded enterprises come to China to invest and set up Sino-foreign joint ventures. Since Schindler established the first industrial Sino-foreign joint venture in China in 1980, the market share of Sino-foreign joint venture in China has been increasing continuously. It can be seen that, nowadays, Sino-foreign joint ventures are of great significance to Chinese economy, and the success of Sino-foreign joint ventures is closely related to every one of us.

Different countries have different traditions and different cultures, while different traditions and different cultures usually lead to cultural conflicts. David A. Ricks, an American scholar, in his book Big Business Blunders, pointed out that many multinational companies failed because of the neglect of cultural conflicts (Ricks, 1989). In organizational behavior, cultural conflict is divided into positive cultural conflict and negative cultural conflict. Positive cultural conflict enables organizations to pool wisdom, while negative cultural conflict leads to low organizational efficiency. Whether the impact of cultural conflict on Sino-foreign joint venture is positive or negative depends on how Sino-foreign joint venture deals with cultural conflict. It can be said that cultural conflict is a double-edged sword-If handled well, it is an opportunity for Sino-foreign joint ventures; if not, it is a challenge for Sino-foreign joint ventures. The best way to turn the challenge of cultural

GAO Yufeng, undergraduate student, School of Foreign Languages, Wuhan University of Technology, Wuhan, China.

Correspondence concerning this article should be addressed to GAO Yufeng, School of Foreign Languages, Wuhan University of Technology, No.122 Luoshi Street, Hongshan District, Wuhan, Hubei, P.R.C. 
conflict into opportunity is the appropriate cross-cultural management model.

FAW-Volkswagen, headquartered in Changchun City, Jilin Province, PRC, was established on February 6, 1991. As one of the most successful Sino-foreign joint ventures in China, FAW-Volkswagen has accumulated a lot of fruitful experience in the field of cross-cultural management. Its cross-cultural management experience, through study and summary, is of great significance for other Sino-foreign joint ventures. The research purpose of this paper is to find out general cross-cultural management methods applicable to other Sino-foreign joint ventures under the guidance of Corporate Culture Theory, Cross-Cultural Management Theory, and other related theories.

\section{Literature Review}

\section{Corporate Culture Theory and Cross-Cultural Management Theory}

Corporate culture is the spiritual and material wealth created by a company with its own characteristics. In the book, The New Corporate Cultures, Terrence E. Deal and Allan A. Kennedy divided corporate culture into five elements: corporate environment, corporate value, heroes, cultural ritual, and cultural net (Deal \& Kennedy, 1999). Usually, corporate culture can be simply divided into four levels: corporate system culture, corporate material culture, corporate behavior culture, and corporate spiritual culture. Corporate system culture refers to the rules and regulations of the enterprise. Corporate material culture consists of the products created by employees and various material facilities. Corporate behavior culture refers to the activity culture produced by enterprise people in production and operation. Corporate spirit culture refers to the cultural concept formed in the process of production.

In 1981, William Ouchi proposed "Z Theory" in "Theory Z: How American Business Can Meet the Japanese Challenge", which believed that in addition to corporate tradition and corporate ethos, corporate value was also an important part of corporate culture (Ouchi, 1981). American scholars Thomas J. Peters and Robert H. Waterman pointed out that all good companies must have their own corporate cultures in Pursuit of Excellence; Striving for Excellence (Peters \& Waterman, 2007). It can be seen that corporate culture plays an important role in guiding the enterprise, and having a proper corporation culture is often the key to the success of an enterprise.

When dealing with the corporate culture of Sino-foreign joint ventures, we usually introduce the concept of Cross-Cultural Management Theory. Cross-cultural management refers to the effective management process of overcoming the conflicts of different cultures under cross-cultural conditions and creating the unique culture of an enterprise. In general, cross-cultural management needs to carefully explore the following questions: (1) How to determine the corporate culture of the enterprise? (2) How to determine the cross-cultural management strategy of the enterprise - cultural assimilation, cultural compromise, or cultural integration? (3) How to lead the enterprise value to employees from different countries?

\section{Cultural Differences Between China and Germany}

Many examples tell us that corporate culture is often associated with national culture. Therefore, researching the general cultural differences between China and Germany is particularly important to understand the cultural conflicts of FAW-Volkswagen.

Confucianism, which emerged in the pre-Qin period, was the mainstream thought in ancient China. Under the influence of Confucianism, the Chinese value harmony and responsibility. By contrast, Protestantism and 
Catholicism are popular in Germany. Protestantism and Catholicism both believe in God and believe that God is merciful. God requires that people should care for each other. Influenced by these concepts, German culture advocates personal values and emphasizes the needs of individuals at a high level. To sum up, it can be concluded that the cultural differences between China and Germany mainly focus on the differences in thinking mode and the differences in behavior mode.

1. The differences in thinking mode. The Chinese consider things from the whole to the details, whereas the Germans consider things from the details to the whole. For example, the Chinese first say year, next say month, then say day; the Chinese first say family name, then say given name, while the Germans first say day, then say month, next say year; the Germans first say given name, then say family name.

2. The differences in behavior mode. Compared with the Germans, the Chinese place more emphasis on social relation and social acceptance. Compared with the Chinese, the Germans place more emphasis on the importance of "private time" and "private space”.

Table 1

Cultural Differences Between China and Germany

\begin{tabular}{lll}
\hline & China & Germany \\
\hline Thinking mode & $\begin{array}{l}\text { considering things from the whole to the details } \\
\text { social relation } \\
\text { Behavior mode }\end{array}$ & $\begin{array}{l}\text { considering things from the details to the whole } \\
\text { private time } \\
\text { srivate space }\end{array}$ \\
\hline
\end{tabular}

\section{Introduction and Analysis of the Corporate Culture of FAW-Volkswagen}

\section{Corporate System Culture}

As for the organizational structure of FAW-Volkswagen, Board of Directors (BOD) is the highest authority of FAW-Volkswagen. BOD is composed of Chinese and German shareholders. Board of Operation and Management (BOM) is established under BOD, which is responsible for the daily operation and management business of FAW-Volkswagen. BOM consists of five members: General Manager (Chinese), Deputy General Manager of Commerce (Chinese), Deputy General Manager of Personnel (Chinese), Deputy General Manager of Finance (German), and Deputy General Manager of Technology (German). Among them, Deputy General Manager of Finance is the First Deputy General Manager.

The organizational structure of FAW-Volkswagen is as follows:

Table 2

The Organizational Structure of FAW-Volkswagen

Board of Directors (BOD)

Board of Operation and Management (BOM)

\begin{tabular}{lllll}
\hline $\begin{array}{l}\text { General Manager } \\
\text { (Chinese) }\end{array}$ & $\begin{array}{l}\text { Deputy General } \\
\text { Manager of Finance } \\
\text { (German) }\end{array}$ & $\begin{array}{l}\text { Deputy General } \\
\text { Manager of Commerce } \\
\text { (Chinese) }\end{array}$ & $\begin{array}{l}\text { Deputy General } \\
\text { Manager of Personnel } \\
\text { (Chinese) }\end{array}$ & $\begin{array}{l}\text { Deputy General } \\
\text { Manager of Technology } \\
\text { (German) }\end{array}$ \\
\hline
\end{tabular}

It can be found that, the General Manager of BOM is the representative of Chinese side, which is in line with the situation of Chinese side holding more than $50 \%$ shares. Since the beginning of the new century, China's automobile market has developed rapidly and consumers' demands have become increasingly diversified. Because of the above market environment, FAW-Volkswagen is facing unprecedented market competition. In FAW-Volkswagen, China side, as the local party, has rich market experience, while Germany 
side has rich manufacturing experience. The huge market demand, on the one hand, highlights the advantages of China side's mature market management system, on the other hand, highlights the advantages of Germany side's mature product research and development system. To sum up, in FAW-Volkswagen, China side has advantages in market (commerce) and talent (personnel), while Germany side has advantages in technology. The organizational structure of FAW-Volkswagen effectively enables China side and Germany side to realize complementary advantages in commerce, personnel, finance, and technology, thus making FAW-Volkswagen gain the largest market competitiveness.

\section{Corporate Material Culture}

In China, FAW-Volkswagen deepens the localization strategy of production. In order to meet the Chinese people's mentality of taking cars as a symbol of identity and status, FAW-Volkswagen launches a lot of extended versions of vehicles. For example, when Audi A6 was first introduced to China, FAW-Volkswagen agreed to increase the wheelbase of Audi A6 by $90 \mathrm{~mm}$ with the advice of the Chinese side. The longer and wider body of Audi A6 is in line with the aesthetic concept of Chinese. Since then, the "longer wheelbase" has been copied by lots of rivals. Besides, Jetta, the third brand of FAW-Volkswagen that has opened up a new realm of youthful car life, has been officially released in Chengdu in 2019. The launch of Jetta brand is favored by many domestic consumers. Nowadays, FAW-Volkswagen's three brands, Volkswagen, Audi, and Jetta have diversified products, and the five production bases of FAW-Volkswagen (Changchun Base, North China Base, East China Base, South China Base, Southwest China Base) spread all over China. It is not difficult to find that, the localization strategy of production is of great significance to the transnational operation of enterprises.

Furthermore, FAW-Volkswagen regards "localization of the whole value chain" as its core development strategy and helps domestic partners to grow from multiple dimensions such as technical support, personnel training, and management optimization, etc., by which FAW-Volkswagen cultivates a large number of local suppliers. At the same time, all local suppliers entering the FAW-Volkswagen purchasing system must meet the requirements of Konzern Produktions System (KPS) of Germany. Obviously, comprehensive considering the standards of both sides of the joint venture is the delicate point of FAW-Volkswagen's cross-cultural management methods.

\section{Corporate Behavior Culture}

Influenced by Confucianism, the popular management thought in China has a certain tendency of moral restraint. By contrast, the popular management thought in Germany has a certain tendency of rule-bound. Due to the objective existence of cultural differences between China and Germany, there are some differences in the behavior habits of Chinese and German managers and employees of FAW-Volkswagen. In dealing with the above issues, FAW-Volkswagen has effectively taken into account the differences in behavior habits between Chinese and German personnel. For example, in terms of post technical training for personnel involved in vehicle production, FAW-Volkswagen divides workers into stamping team, welding team, painting team, and final assembly team according to the four core links of vehicle production. Each team will be jointly managed by managers from both China side and Germany side. In this way, the problem of personnel behavior differences between China and Germany is maximally coordinated. In addition to that, the management levels of both Chinese side and German side of FAW-Volkswagen are constantly learning the management thoughts of the other side and making efforts to further integrate the management models of the two sides. It is not 
difficult to find, properly coordinating and balancing the behavior habits of two parties in a joint venture should become one of the core ideas of cross-cultural management.

\section{Corporate Spirit Culture}

FAW-Volkswagen takes “study, progress, cooperation and innovation (学习、进取、合作、创新)” as its enterprise spirit. It is not difficult to find that FAW-Volkswagen emphasizes "cooperation" in its enterprise spirit. In a Sino-foreign joint venture, the two parties can achieve maximum benefits only by taking the initiative to participate and cooperate. More importantly, FAW-Volkswagen is deeply aware of the influence of language on culture. Therefore, there are regular elementary, intermediate, and advanced German training classes for employees in FAW-Volkswagen. Anyone who signs up can attend the German training classes. Language learning enables employees to view cultural differences from a broader perspective, which is of great significance for the enterprise to form a unified corporate spirit culture. In addition to language training, FAW-Volkswagen also holds regular Sino-German staff fellowship activities. In a word, as a Sino-foreign joint venture, it should be deeply aware of the importance of training its personnel in language, culture, and even cross-culture concepts.

\section{Conclusion}

Cultural conflicts are inevitable for Sino-foreign joint venture due to the objective existence of cultural differences between two sides of the joint venture, while scientific cross-cultural management methods can help Sino-foreign joint ventures to turn the challenge of cultural conflict into opportunity. Based on the above research, the following general cross-cultural management methods applicable to other Sino-foreign joint ventures can be obtained.

First of all, in a Sino-foreign joint venture, both parties often have their own advantages. Therefore, the Sino-foreign joint venture should take the form of system to enable both parties to take charge of their respective areas of advantages, so as to maximize the overall market competitiveness of the Sino-foreign joint venture. Secondly, the Sino-foreign joint venture should fully consider the cultural differences in product production area and properly use the localization strategy of production to open up more market space. Thirdly, the Sino-foreign joint venture should take into account the differences in the behavior habits of two parties, coordinate the behavior habits of two parties, and thus foster a unified enterprise spirit. Fourthly, the corporate spirit culture of the Sino-foreign joint venture should be neither the corporate spirit culture of one party nor the simple superposition of the corporate spirit cultures of two parties, but the organic combination of the corporate spirit cultures of two parties. As a Sino-foreign joint venture, its corporate spirit culture should emphasize "inclusive development”, which is the most effective means to solve cultural conflicts. Finally, the Sino-foreign joint venture should pay more attention to language training, culture training, and even cross-culture training for employees.

With the development of China's economy, Sino-foreign joint ventures will become more and more common and occupy a larger and larger market share in the future. Cross-cultural management is a link connecting different cultures. Properly cross-cultural management methods play a decisive role in the successful operation of Sino-foreign joint ventures and even the steady long-term development of China's economy in the future. 


\section{References}

Deal, T. D., \& Kennedy, A. A. (1999). The new corporate cultures. New York: Perseus Books Group.

Ouchi, W. (1981). Theory Z: How American business can meet the Japanese challenge. Business Horizons, 24(6), 82-83.

Peters, T. J., \& Waterman, R. H. (2007). Pursuit of excellence; striving for excellence. Beijing: China CITIC Press. (In Chinese)

Ricks, A. D. (1989). Big business blunders. Homewood: Dow Jones-Irwin 